\title{
The Drainage Bag Additive Saga
}

The cost of medical care has risen rapidly in recent years due largely to the introduction of new and more expensive technology and the need for skilled personnel to manage the devices. Even the lowly catheter and its drainage bag considerably influence medical care costs. Despite their low unit cost, the overall expenditure by hospitals for indwelling urinary catheter systems is considerable. Catheters are used in about $10 \%$ of the over 30 million patients admitted to acute care hospitals in the US each year. The urinary catheter is the leading cause of hospital-acquired infections. It accounts each year for thousands of episodes of gram-negative bacteremia and sepsis, infections of the bladder, kidney, prostate and adjacent structures as well as metastatic infection often to the vertebrae. These infections produce considerable human suffering and generate large expenditures for diagnostic procedures and antimicrobial therapy and they prolong hospital stay. ${ }^{1,2}$

Because of the great importance of catheter-associated infections it is tempting to adopt measures which promise to improve catheter care, even before they are proven to be effective in well-designed clinical trials. The hospital infection control officer has the key responsibility in his or her institution to evaluate critically the claims made for each method and to make appropriate recommendations to the medical staff and hospital administration. A simple matter such as whether or not to add antibacterial compounds to urinary drainage bags may greatly reduce or increase hospital costs depending on whether or not it is effective.

Catheter drainage bags can become contaminated by bacteria entering the drainage port when the bags are emptied, or upon breaking the junction of the catheter and drainage tube. Bacteria can also be passed into the bag from colonized bladder urine. It would appear reasonable to try to prevent contamination of the system by

From the Department of Medicine, The Ohio State University, Columbus, Ohio.

Address reprint requests to Calvin $M$. Kunin, $M D$, Pomerene Professor of Medicine, Department of Medicine, The Ohio State University, $\mathrm{Rm} M 110$ Starling-Loving Hall, 320 W. 10th Avenue, Columbus, OH 43210-1240. adding an effective and nontoxic antimicrobial compound to the drainage bag. This would hopefully provide a barrier, in addition to closed drainage, to prevent bacteria from ascending from the drainage bag into the bladder and might prevent cross-infection among patients. The concept of adding disinfectants to drainage bags is not new. More than 55 years ago Dukes added a mercurial to the collection bottle in a closed drainage system. ${ }^{3}$ More recently, encouraging reports appeared which claimed that the frequency of bladder bacteriuria was reduced in catheterized patients by addition to the drainage bag of hydrogen peroxide or povidone iodine or chlorhexidine. ${ }^{4,6}$ Based on the results of some of these studies, a system for instilling hydrogen peroxide into drainage bags became available commercially in this country.

There is strong evidence, however, that addition of antibacterial substances to urinary drainage bags is not effective. Several well-controlled trials demonstrate conclusively that adding hydrogen peroxide or chlorhexidine to drainage bags does not prevent acquisition of catheter-associated bladder bacteriuria. ${ }^{7,8}$ The report by Sweet et al, in this issue, using somewhat different methods to assure that catheters have been in place for 5 days or longer, confirms these reports.

It is not difficult to understand why this apparently rational method does not work. The reasons are that aseptic closed drainage prevents colonization of the drainage bag and subsequent ascending infection for about the first week or two after a catheter is inserted into the bladder. Thereafter a second mode of colonization of the bladder urine becomes increasingly more important. This is due to entry into the bladder of bacteria which colonize the intraurethral sheath around the catheter. Enteric gram-negative bacilli, enterococci and Staphylococcus epidermidis, which grow well in urine, begin to colonize the catheter surface and enter and multiply in the bladder urine. Persistent infection is aided by the continued presence of the catheter which acts as a foreign body and reservoir of bacteria.

In studies conducted with McCormack some years ago, ${ }^{9}$ I found that colonization of the drainage bag occurred in most cases at about the same time in urine 
collected from both the catheter and bag. This observation suggested that in the presence of closed drainage, bladder bacteriuria was acquired from some route other than ascent from the bag. Schaeffer noted also that the drainage bag was not the source of acquisition of bacteriuria in patients cared for in a protected environment, but was due to urethral organisms or break of the drainage system. ${ }^{10}$ Kass and Schneiderman had demonstrated previously that bacteria can colonize the outside surface of the catheter and migrate directly into the bladder. ${ }^{11}$ More recently, Garibaldi and co-workers, and Daifuku and Stamm have provided strong evidence that meatal colonization followed by migration of bacteria around the catheter accounts for acquisition of infection. ${ }^{12,13}$ We examined bacterial colonization of catheters after they were removed from patients as a means of sampling the intraurethral flora. ${ }^{14}$ We were able to document the gradual colonization of the urethra with gram-negative bacilli and enterococci. Females became colonized more rapidly than males. This corresponds to their earlier acquisition of catheter-induced infections.

The "drainage bag additive saga" is one of many instances in which well-meaning and apparently rational measures in medical practice simply do not live up to expectations. This is because bacterial biologic systems are complex and baffle even the keenest minds. There is considerable danger in introducing a new mode of practice before it has been subjected to adequate clinical trial. No one gains. The manufacturer of the hydrogen peroxide system will have to remove the product from the market or limit its claims substantially. The hospitals that have purchased the product have spent their funds unwisely. The major gains from this effort is that we have learned a bit more about the mechanism of acquisition of catheter-induced urinary tract infections and perhaps will be more cautious in accepting inadequately proven methods. Nevertheless, as Schaeffer suggests, there still may be a place for a truly effective antibacterial barrier to prevent cross-infecton from contaminated drainage bag urine among patients in crowded hospital units. ${ }^{10}$ This might reduce the mini-epidemics of nosocomial multi-resistant bacteria. ${ }^{15,16} \mathrm{~A}$ compound more active than hydrogen peroxide, possibly chlorhexidine, will be needed for this purpose. Based on the well known ability of bacteria to develop resistance, even this approach may be short lived.

\section{REFERENCES}

1. Kunin CM: Genitourinary infections in the patient at risk: Extrinsic risk factors. Am J Med 1984; 75(5A):131-139.

2. Givens CD, Wenzel RP: Catheter-associated urinary tract infections in surgical patients: A controlled study on the excess morbidity and costs. J Urol 1980; 124:646-648.

3. Dukes C: Urinary infections after excision of the rectum: Their cause and prevention. Proceedings of the Royal Society of Medicine 1928; $22: 1-11$.

4. Maizels M, Schaeffer AJ: Decreased incidence of bacteriuria associated with periodic instillations of hydrogen peroxide in the urechral catheter drainage bag. J Urol 1980; 123:841-845.

5. Evans AT, Cicmanic JF: The role of Betadine microbicides in urine bag sterilization, in Proceedings of the Second World Congress on Antisepsis, New York, H.P. Publishing, 1980, pp 85-86.

6. Southampton Infection Control Team. Evaluation of aseptic techniques and chlorhexidine on the rate of catheter-associated urinarytract infection. Lancet 1982; 1:89-91.

7. Thompson RL, Haley CE, Searcy MA, et al: Catheter-associated bacteriuria: Failure to reduce attack rates using periodic instillations of a disinfectant into urinary drainage systems. JAMA 1984: $251: 747-751$.

8. Gillespie WA, Jones JE, Teasdale $C$, et al: Does the addition of disinfectant to urine drainage bags prevent infection in catheterized patients? Lancet 1983; 2:1037-1039.

9. Kunin CM, McCormack RC: Prevention of catheter-induced urinary tract infections by sterile closed drainage. N Engl J Med 1966; 274:1156-1161.

10. Schaeffer AJ: Catheter-associated bacteriuria in patients in reverse isolation. J Urol 1982; 128:752-754

11. Kass EH, Schneiderman LJ: Entry of bacteria into the urinary tracts of patients with inlying catheters. N EnglJ Med 1957; 256:556-557.

12. Garibaldi RA, Burke JP, Britt MR, et al: Meatal colonization and catheter-associated bacteriuria. $N$ Engl J Med 1980; 303:2 16-218.

13. Daifuku R, Stamm WE: Association of rectal and urethral colonization with urinary tract infection in patients with indwelling catheters. JAMA 1984; 252:2028-2030.

14. Kunin CM, Steele C: Culture of the surface of urinary catheters to sample the urethral flora and study the effect of antimicrobial therapy. J Clin Microbiol 1985, to be published.

15. Maki DG, Hennekens CG, Phillips CW, et al Nosocomial urinary tract infection with Serratia marscescens: An epidemiologic study.J Infect Dis 1973; 128:579-587.

16. Schaberg DR, Alford RH, Anderson R, et al: An outbreak of nosocomial infection due to multiply resistant Serratia marscescens: Evidence for interhospital spread. J Infect Dis 1976; 134:181-188. 